\title{
PENERAPAN CULTURAL STUDIES DAN ALIRAN FILSAFAT DALAM DESAIN KOMUNIKASI VISUAL
}

\author{
Laura Christina Luzar; Monica \\ Visual Communication Design, School of Design, BINUS University \\ Jln. K.H. Syahdan No. 9, Palmerah, Jakarta Barat 11480 \\ lluzar@binus.edu; monica.wiguno@gmail.com
}

\begin{abstract}
Cultural studies is a diversity knowledge from different variety of perspectives, through the production of theory trying to intervene in political culture. Cultural studies explores culture as a practice purport in the context of social force. In this case, cultural studies is not only based on one point only, but also cultural studies tries to compose a variety of theoretical studies of other disciplines developed wider, so that covers a wide range of academic theories that already existed, including Marxism, Structuralism, Post-structuralism, and feminism. By eclectic method, cultural studies puts the positioning to all knowledges, including on its knowledge which integrates with culture, practice of signification, representation, discourse, authority, articulation, text, read, and consumption. Cultural studies could be described as a language game or formation of discourse associated with relation to power in signification practice of human life. In addition to cultural studies, there is also feminism theory participated in the concept of feminist cultural studies that reconstructs and transforms view of misperception between feminism and cultural studies. Feminism affects cultural studies, but not all feminism can be viewed as cultural studies, and not all cultural studies talks about gender. Both of cultural studies and feminism have substantive importance in relation to power, representation, pop-culture, subjectivity, identity and consumption. The theory of social construction is also has connectivity with cultural studies. Construction of reality is inseparable from mark, symbol, and language. Media are full of reality constructed for people to affect people as ethics persuasion in media do.
\end{abstract}

Keywords: cultural studies, feminism, social construction

\begin{abstract}
ABSTRAK
Cultural studies adalah keragaman pengetahuan dari berbagai perspektif yang berbeda, melalui produksi teori berusaha untuk mengintervensi politik budaya. Cultural studies mengeksplorasi kebudayaan sebagai praktik pemaknaan dalam konteks kekuatan sosial. Dalam hal ini, cultural studies tidak hanya berpusat pada satu titik saja, cultural studies berusaha mengomposisikan berbagai kajian teoretis disiplin ilmu lain yang dikembangkan secara lebih luas, sehingga mencakup berbagai keilmuan dari teori yang sudah ada, termasuk teori Marxisme, Strukturalisme, Post-strukturalisme, dan Feminisme. Dengan metode eklektis, cultural studies menempatkan posisi pada semua pengetahuan, termasuk pada pengetahuannya sendiri, yang menyatu dengan kebudayaan, praktik signifikasi, representasi, diskursus, kekuasaan, artikulasi, teks, membaca, dan konsumsi. Cultural studies dapat dideskripsikan sebagai permainan bahasa atau pembentukan wacana yang terkait dengan isu kekuasaan dalam praktik signifikasi kehidupan manusia. Selain cultural studies, terdapat pula teori feminis yang berperan dalam mengonstruksikan konsep cultural studies feminis, mentransformasikan pandangan tentang persepsi yang salah antara feminisme dengan cultural studies. Feminisme memang memengaruhi cultural studies, tetapi tidak semua feminisme dapat dipandang sebagai cultural studies dan tidak semua cultural studies berbicara mengenai gender. Cultural studies dan feminisme sama-sama memiliki kepentingan substantif dalam isu kekuasaan, representasi, budaya pop, subjektivitas, identitas dan konsumsi. Teori konstruksi sosial juga memiliki keterkaitan dengan cultural studies. Konstruksi realitas tidak terlepas dari tanda, simbol, dan bahasa. Dunia media penuh dengan realitas yang dikonstruksikan bagi masyarakat untuk memengaruhi masyarakat seperti halnya etika persuasi dalam media.
\end{abstract}

Kata kunci: cultural studies, feminisme, konstruksi sosial 


\section{PENDAHULUAN}

Dewasa ini, cultural studies dianggap sebagai kajian yang mendeskripsikan fenomenafenomena masyarakat kontemporer, antara lain pada budaya pop, media, sub-culture, gaya hidup, konsumerisme, identitas lokal, dan lain-lain. Media pada praktiknya diposisiskan dalam totalitas ekspresif yang kompleks dan menggunakan perspektif holistik yang bersifat makro sebagai kondisi yang mendasari sosiologi budaya. Fenomena kontemporer ditandai oleh menguatnya budaya massa melalui media komersil, khususnya televisi. Perkembangan teknologi komunikasi serta munculnya media-media baru menyebabkan terbentuknya masyarakat informasi serta isu globalisasi yang merupakan gejala fenomena masyarakat kontemporer.

Dengan demikian, muculnya cultural studies di dalam komunikasi massa bukanlah merupakan suatu hal yang hanya berlandaskan pada media dan dampaknya, namun merupakan suatu kajian mutakhir pada era postmodern yang membahas mengenai isu-isu kontemporer komunikasi dari perspektif cultural, yang diposisikan sebagai fenomena komunikasi. Bagi kajian komunikasi massa, cultural studies merupakan sebuah pandangan dari perspektif ilmu komunikasi yang telah ada selama ini. Hal ini dapat memperkaya sudut pandang bagi para peminat komunikasi dalam memahami realitas komunikasi dan kebudayaan sebagai hal yang saling berkaitan.

Selain itu, cultural studies ingin memainkan peran demistifikasi, untuk menunjukkan karakter terkonstruksi teks-teks kebudayaan dan berbagai mitos dan ideologi yang tertanam, dengan harapan dapat melahirkan posisi-posisi subjek. Cultural studies diharapkan dapat mengorganisasi berbagai kelompok oposisi menjadi suatu aliansi politik kebudayaan. Sedangkan dari segi metode penelitian komunikasi, cultural studies dapat memperkuat posisi etnografi, pendekatan tekstual (semiotika dan teori narasi), serta kajian-kajian sebagai suatu metode yang relevan untuk diterapkan dalam ilmu sosial.

Feminisme sering kali dianggap sebagai pendatang yang terlambat dalam ranah kajian cultural studies. Teori feminis awalnya hadir sebagai teori penindasan gender dalam budaya. Oleh karena itu, teori feminis kemudian berlanjut pada eksplorasi Gerakan Pembebasan Perempuan. Teori feminis ini berperan dalam mengonstruksikan konsep cultural studies feminis, serta mentransformasikan pandangan tentang persepsi yang salah antara feminisme dengan cultural studies. Feminisme mempengaruhi cultural studies, namun tidak semua feminisme dapat dipandang sebagai cultural studies dan tidak semua cultural studies berbicara mengenai gender. Cultural studies dan feminisme sama-sama memiliki kepentingan substantif dalam isu kekuasaan, representasi, budaya pop, subjektivitas, identitas dan konsumsi. Dalam cultural studises, seks dan gender diyakini sebagai konstruksi realitas sosial yang secara intrinsik terkandung dalam persoalan representasi.

\section{METODE}

Penulisan berdasarkan studi literature. Data diperoleh ari berbagai sumber yang terkait dengan keilmuan filsafat, desain komunikasi visual dan teori pendukungnya, baik dari media cetak maupun media elektronik. Kemudian berdasarkan data, hasil pengamatan dan analisis di lapangan diseleksi, dievaluasi, dan disimpulkan menjadi pendukung dalam penulisan ini. 


\section{HASIL DAN PEMBAHASAN}

\section{Cultural Studies}

Lahir di tengah semangat Neo-Marxisme yang berupaya untuk meredefinisikan Marxisme, sebagai perlawanan terhadap dominasi dan hegemoni budaya tertentu. Cultural studies berakar dari gagasan Karl Marx, yang mempunyai pandangan bahwa kapitalisme telah menciptakan kelompok elit kuasa untuk melakukan eksploitasi terhadap kelompok yang tidak berkuasa dan lemah. Pengaruh kontrol kelompok berkuasa terhadap yang lemah menjadikan kelompok yang lemah merasa tidak memiliki kontrol atas masa depan mereka. Para pendiri cultural studies memiliki latar belakang pendidikan Sastra, dapat ditilik dari perkembangan paham strukturalisme dalam kritik-kritik Sastra yang berkembang pesat di Eropa pada masa itu. Cultural Studies adalah studi kebudayaan atas praktik signifikasi representasi, dengan mengeksplorasi pembentukan makna pada beragam konteks.

Berikut ini adalah karakteristik cultural studies menurut Sardar dan Van Loon. Cultural studies mengkaji berbagai kebudayaan dan praktik budaya serta kaitannya dengan kekuasaan. Tujuannya adalah mengungkapkan hubungan kekuasaan serta mengkaji bagaimana hubungan tersebut memengaruhi berbagai bentuk kebudayaan (sosial-politik, ekonomi, ilmu pengetahuan, hukum dan lain-lain). Cultural studies tidak hanya merupakan studi tentang budaya yang merupakan entitas tersendiri yang terpisah dari konteks sosial dan politiknya. Tujuannya adalah memahami budaya dalam segala bentuk kompleksnya dan menganalisis konteks sosial dan politik tempat budaya tersebut berasal. Budaya dalam cultural studies menampilkan 2 fungsi, merupakan objek studi maupun lokasi tindakan dan kristisme politik. Cultural studies bertujuan baik sebagai usaha pragmatis maupun ideal. Cultural studies berupaya untuk mendobrak pengotak-ngotakan pengetahuan konvensional, berupaya mendamaikan dan mengatasi perpecahan antara bentuk pengetahuan yang tidak tersirat (pengetahuan intuitif berdasarkan budaya lokal) dan yang objektif (universal). Cultural studies mengasumsikan suatu identitas dan kepentingan bersama antara yang mengetahui dengan yang diketahui, antara pengamat dengan yang diamati. Cultural studies melibatkan diri dengan evaluasi moral masyarakat modern dengan garis radikal tindakan politik. Cultural studies bertujuan memahami dan mengubah struktur dominasi khususnya dalam masyarakat kapitalis industri.

Istilah budaya mencakup beberapa hal, mulai dari produk budaya, simbol budaya, perilaku budaya, gagasan serta sudut pandang yang mendasari perilaku tertentu (perspektif budaya). Teori cultural studies memiliki landasan bahwa manusia, komunikasi, masyarakat dan budaya saling berpengaruh satu sama lain, disebut dengan teori logika depedensi. Konsep cultural studies menurut Morison dapat dipahami dari beberapa aspek, yaitu sebagai berikut. Ideologi budaya; budaya adalah kumpulan makna-makna, dan masyarakat adalah subjek yang menciptakan makna tersebut secara aktif dan terus menerus. Pemaknaan simbol-simbol tersebut selalu berbeda, maka terjadi perbedaan pemaknaan terhadap simbol atau perang budaya. Perbedaan terjadi ketika sebuah sistem budaya menginginkan pemaknaan " $\mathrm{A}$ " pada simbol "A" sementara budaya lain menginginkan makna " $\mathrm{A}$ " adalah "B". Budaya yang berhasil menanamkan makna lebih dalam, menjadi budaya pemenang dan pengatur masyarakat. Ketika menjadi satu-satunya ideologi budaya yang menjadi sandaran masyarakat, maka terjadilah imperialisme kebudayaan. Hegemoni kebudayaan; hegemoni adalah konsep yang mewakili pengaruh, kekuasaan atau dominasi kelompok sosial tertentu atas kelompok lainnya. Hegemoni budaya berarti kontrol sebuah kelompok atas kelompok lainnya melalui budaya. Konsep hegemoni banyak digunakan oleh sosiolog untuk menjelaskan fenomena terjadinya usaha untuk mempertahankan kekuasaan oleh pihak penguasa. Struktur kekuasaan; manusia merupakan bagian dari kekuasaan, yang setiap orang merupakan bagian kekuasaan pada tingkat yang berbeda. Kompetisi dalam perebutan kekuasaan sering kali terjadi untuk menentukan makna. Pada umumnya yang menang adalah kelompok yang berada pada puncak hierarki sosial, yaitu media. Dalam hal ini, media menentukan apa makna dari berbagai simbol, masyarakat cenderung hanya menerima makna- 
makna tersebut. Decoding informasi; ketika pesan dikirimkan kepada masyarakat, maka khalayak akan menerima dan membandingkan pesan-pesan tersebut dengan makna sebelumnya yang telah disimpan dalam ingatan. Proses inilah yang disebut dengan decoding. Proses decoding mendapat perhatian dalam cultural studies karena menentukan arti pesan bagi seseorang.

Cultural studies berupaya menganalisis praktik budaya guna membongkar praktik kuasa yang terkait dengan produksi makna. Dalam perkembangannya, cultural studies yang dibentuk sebagai disiplin kajian yang khas, memiliki karakter yang berbeda-beda pada setiap wilayah. Cultural studies Inggris merupakan asal mula terbentuknya cultural studies, dianggap sebagai disiplin yang sudah terlalu formal dan kaku, menuai berbagai kritik karena terlalu Anglosentris (mengukur segala sesuatu dari kacamata budaya Anglo-Saxon). Berbeda dengan cultural studies Amerika Serikat yang berpusat pada pemujaan terhadap budaya pop yang terlalu berlebihan. Cultural studies Prancis mengalami perkembangan yang sangat menarik di tengah pergolakan kelas dan revolusi sosial yang disebabkan oleh kedatangan para imigran. Cultural studies Prancis banyak membicarakan tentang "kesepian" kaum imigran di negara baru dan "kebingungan identitas" di tengah keberagaman Prancis yang menempatkan budayanya sebagai pusat budaya yang lebih superior. Cultural studies India mengangkat semangat perlawanan mengahadapi praktik kolonialisme maupun pascakolonialisme. Cultural studies Indonesia merupakan hasil asimilasi dari tradisi ilmiah yang sangat berbeda dengan keseharian Indonesia dengan mengacu pada kebudayaan negara asal, walaupun sebenarnya Indonesia mempunyai sumber-sumber budaya, sosial dan historis yang tidak kalah unik dibandingkan dengan negara lain.

Cultural studies merupakan model kajian budaya (termasuk sosial) yang berbeda dengan kajian budaya modern (konvensional). Cultural studies tidak dapat diteliti dan dipahami berdasarkan epistemologi modern, karena asumsi dasar kajian ini sangat dipengaruhi oleh pemikiran postmodern. Karakter kajian budaya modern bersifat objektif, universal, monokultural, dan beridentitas tunggal; sedangkan cultural studies memandang budaya bersifat plural, multikultural, kompleks, identitas terkonstruksi, dinamis, berbeda, interaktif, dan saling berpengaruh secara intens karena perbedaan pandangan dunia dan permainan bahasa (language game). Kajian budaya menolak klaim para empirisis bahwa pengetahuan hanyalah masalah mengumpulkan fakta yang digunakan untuk mendeduksi atau menguji teori (Storey, 2007:38-40). Teori dipandang terlalu implisit dalam penelitian empiris melalui pemilihan topik, fokus riset dan konsep-konsep yang dipakai untuk mendiskusikan dan menafsirkannya. Kajian budaya ingin memainkan peran demistifikasi, untuk menunjukkan karakter terkonstruksi teks kebudayaan dan berbagai mitos dan ideologi yang tertanam di dalamnya, agar dapat melahirkan posisi-posisi subjek, yang mampu melawan sub-ordinasi.

\section{Feminisme}

Paham feminisme berpendapat bahwa seks bersifat fundamental dan tidak dapat direduksi menjadi poros organisasi sosial. Fokus pada seks sebagai prinsip pengatur kehidupan sosial, bahwa relasi gender sepenuhnya dipengaruhi oleh relasi kekuasaan. Kekuasaan laki-laki dan subordinasi perempuan berifat struktural, hal ini mendorong para feminis untuk mengadopsi konsep patriarki. Kritik terhadap konsep patriarki terletak pada penjelasan tentang semua perempuan dipandang memiliki kesamaan mendasar yang bertentangan dengan semua laki-laki (Kholifah \& Romadlan, 2011). Feminisme adalah aliran pemikiran dan suatu gerakan yang menuntut pemikiran ulang terhadap kaum perempuan. Pandangan yang menolak pembedaan laki-laki dan perempuan yang dikonstruksikan secara sosial dan budaya. Feminisme memperjuangkan kemanusiaan kaum perempuan, sebagai manusia merdeka menuju tatanan hubungan-hubungan sosial baru, bahwa perempuan sama dengan laki-laki menjadi subjek utuh dalam membuat keputusan, dalam alokasi kekuasaan dan sumber-sumbernya. Feminisme berpihak pada perempuan yang ditindas, didiskriminasi, diekploitasi, serta diabaikan. 
Feminisme Radikal melihat tegas hubungan atau relasi kekuasaan laki-laki dan perempuan, sumber masalahnya adalah ideolegi patriarki. Terdapat pandangan bahwa penindasan terhadap perempuan terjadi akibat sistem patriarki. Tubuh perempuan merupakan objek utama penindasan oleh kekuasaan laki-laki. Oleh karena itu, feminisme radikal mempermasalahkan hal-hal seperti tubuh serta hak-hak reproduksi, seksualitas (termasuk lesbianisme), seksisme, relasi kuasa perempuan dan lakilaki, dan dikotomi privat-publik. Feminisme radikal percaya pada pentingnya otonomi dan gerakan perempuan, serta melihat persoalan personalitas perempuan tidak boleh dipisahkan dengan persoalan publik. Aliran ini menawarkan ideologi "perjuangan separatisme perempuan", yang muncul sebagai reaksi atas kultur seksisme atau dominasi sosial berdasarkan jenis kelamin di Barat pada tahun 1960-an, tujuannya adalah melawan kekerasan seksual dan industri pornografi. Pemahaman penindasan laki-laki terhadap perempuan merupakan fakta yang terjadi dalam sistem masyarakat sekarang ini.

Feminisme radikal terjadi di Ukraina, sekelompok perempuan yang merupakan anggota organisasi feminis radikal Femen. Mereka melakukan aksi protes untuk melawan prostitusi. Selain itu mereka juga melakukan aksi protes bahwa perempuan di Ukraina sulit untuk mendapatkan pekerjaan, laki-laki mendominasi setiap sektor dan kerap bermabuk-mabukan dan melakukan kekerasan seksual terhadap perempuan. Gerakan ini berupaya untuk mengubah nasib perempuan yang tertindas. Target utama aksi mereka adalah isu perdagangan perempuan, dimana para perempuan di Ukraina amat rentan terhadap aksi penculikan kemudian dijual ke industri pornografi. Cultural Studies berfungsi untuk menganalisis praktik budaya dan struktur kekuasaan yang terjadi pada suatu kawasan. Cultural Studies digunakan dalam kajian desain untuk mengeksplorasi pembentukan makna pada beragam konteks, misalnya saja penciptaan suatu desain yang diperuntukkan untuk mendukung semangat perlawanan terhadap bentuk kekerasan terhadap perempuan. Cultural Studies berfungsi untuk menganalisis praktik budaya dan struktur kekuasaan yang terjadi pada suatu kawasan.

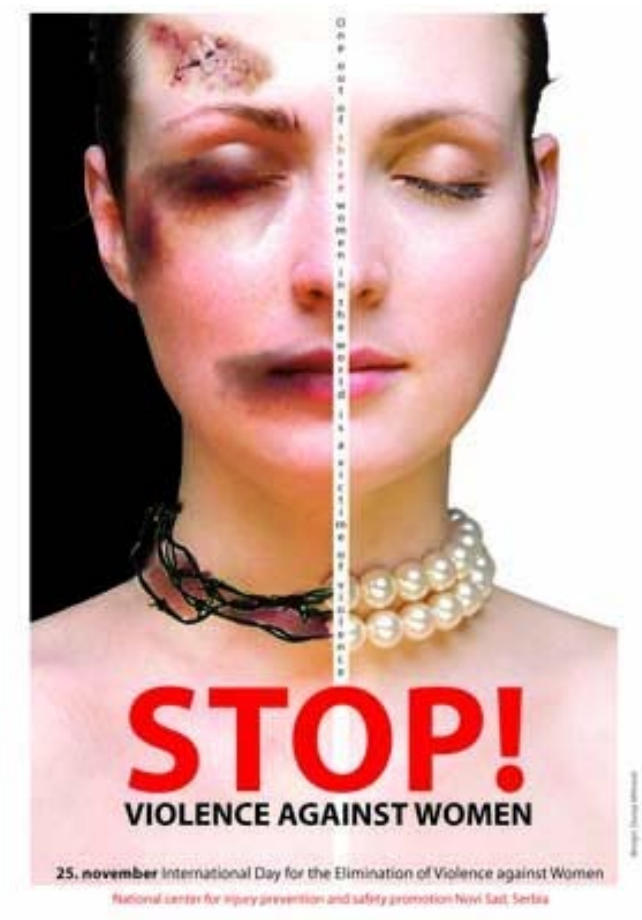

Gambar 1 Poster "Stop Kekerasan Terhadap Perempuan”. (Sumber: quince, 2014) 


\section{Teori Konstruksi Realitas Sosial}

Konstruksi Sosial atas Realitas (Social Construction of Reality) didefinisikan sebagai proses sosial melalui tindakan dan interaksi dimana individu atau sekelompok individu, menciptakan secara terus-menerus suatu realitas yang dimiliki dan dialami bersama secara subjektif. Teori ini berakar pada paradigma konstruktivis yang melihat realitas sosial sebagai konstruksi sosial yang diciptakan oleh individu, yang merupakan manusia bebas (Bungin, 2007). Individu menjadi penentu dalam dunia sosial yang dikonstruksi berdasarkan kehendaknya, yang dalam banyak hal memiliki kebebasan untuk bertindak di luar batas kontrol struktur dan pranata sosialnya. Dalam proses sosial, manusia dipandang sebagai pencipta realitas sosial yang relatif bebas di dalam dunia sosialnya.

Konstruksi sosial merupakan teori sosiologi kontemporer, dicetuskan oleh Peter L. Berger dan Thomas Luckmann. Teori ini merupakan suatu kajian teoritis dan sistematis mengenai sosiologi pengetahuan (penalaran teoritis yang sistematis), bukan merupakan suatu tinjauan historis mengenai perkembangan disiplin ilmu. Pemikiran Berger dan Luckmann dipengaruhi oleh pemikiran sosiologi lain, seperti Schutzian tentang fenomenologi, Weberian tentang makna-makna subjektif, Durkhemian Parsonian tentang struktur, pemikiran Marxian tentang dialektika, serta pemikiran Herbert Mead tentang interaksi simbolik.

Asal usul kontruksi sosial dari filsafat Kontruktivisme, yang dimulai dari gagasan-gagasan konstruktif kognitif. Dalam aliran filsasat, gagasan konstruktivisme telah muncul sejak Socrates menemukan jiwa dalam tubuh manusia, dan Plato menemukan akal budi. Gagasan tersebut makin konkret setelah Aristoteles mengenalkan istilah, informasi, relasi, individu, subtansi, materi, esensi, dan sebagainya. Ia mengatakan bahwa manusia adalah makhluk sosial, setiap pernyataan harus dapat dibuktikan kebenarannya, serta kunci pengetahuan adalah fakta. Ungkapan Aristoteles "Cogito ergo sum", yang artinya "saya berfikir karena itu saya ada", menjadi dasar yang kuat bagi perkembangan gagasan-gagasan konstruktivisme sampai saat ini.

Seorang epistemolog dari Italia bernama Giambatissta Vico, yang merupakan pencetus gagasan-gagasan pokok Konstruktivisme, dalam "De Antiquissima Italorum Sapientia", mengungkapkan filsafatnya "Tuhan adalah pencipta alam semesta dan manusia adalah tuan dari ciptaan”. Menurutnya, hanya Tuhan sajalah yang dapat mengerti alam raya ini karena hanya Ia yang tahu bagaimana membuatnya dan dari apa Ia membuatnya, sementara itu orang hanya dapat mengetahui sesuatu yang telah dikonstruksikannya.

Terdapat 3 macam Konstruktivisme, antara lain sebagai berikut. Pertama, konstruktivisme radikal; hanya dapat mengakui apa yang dibentuk oleh pikiran, dan bentuknya tidak selalu representasi dunia nyata. Kaum konstruktivisme radikal mengesampingkan hubungan antara pengetahuan dan kenyataan sebagai suatu kriteria kebenaran. Pengetahuan bagi mereka tidak merefleksi suatu realitas ontologism objektif, namun sebuah realitas yang dibentuk oleh pengalaman seseorang. Pengetahuan selalu merupakan konstruksi dari individu yang mengetahui dan tidak dapat ditransfer kepada individu lain yang pasif. Kedua, realisme hipotesis; pengetahuan adalah sebuah hipotesis dari struktur realitas yang mendekati realitas dan menuju kepada pengetahuan yang hakiki. Ketiga, konstruktivisme biasa; mengambil semua konsekuensi konstruktivisme, serta memahami pengetahuan sebagai gambaran dari realitas itu. Pengetahuan individu dipandang sebagai gambaran yang dibentuk dari realitas objektif dalam dirinya sendiri.

Dari ketiga macam konstruktivisme terdapat kesamaan. Konstruktivisme dilihat sebagai proses kerja kognitif individu untuk menafsirkan dunia realitas yang ada, karena terjadi relasi sosial antara individu dengan lingkungan atau orang di sekitarnya. Kemudian Individu membangun sendiri pengetahuan atas realitas yang dilihatnya berdasarkan pada struktur pengetahuan yang telah ada sebelumnya, inilah yang disebut dengan konstruksi sosial menurut Berger dan Luckmann. 
Berger dan Luckman berpendapat bahwa institusi masyarakat tercipta dan dipertahankan atau diubah melalui tindakan dan interaksi manusia, walaupun masyarakat dan institusi sosial terlihat nyata secara objektif, namun pada kenyataannya semua dibentuk dalam definisi subjektif melalui proses interaksi. Objektivitas dapat terjadi melalui penegasan berulang-ulang yang diberikan oleh orang lain, yang memiliki definisi subjektif yang sama. Pada tingkat generalitas yang paling tinggi, manusia menciptakan dunia dalam makna simbolis yang universal, yaitu pandangan hidup menyeluruh yang memberi legitimasi dan mengatur bentuk-bentuk sosial, serta memberi makna pada berbagai bidang kehidupannya.

Menurut Berger dan Luckman, terdapat 3 bentuk realitas sosial. Pertama, realitas sosial objektif, merupakan suatu kompleksitas definisi realitas (termasuk ideologi dan keyakinan) gejalagejala sosial, seperti tindakan dan tingkah laku yang terjadi dalam kehidupan sehari-hari dan sering dihadapi oleh individu sebagai fakta. Kedua, realitas sosial simbolis, merupakan ekspresi bentukbentuk simbolik dari realitas objektif, yang umumnya diketahui oleh khalayak dalam bentuk karya seni, fiksi serta berita-berita di media. Ketiga, realitas sosial subjektif; realitas sosial pada individu, yang berasal dari realitas sosial objektif dan realitas sosial simbolik, merupakan konstruksi definisi realitas yang dimiliki individu dan dikonstruksi melalui proses internalisasi. Realitas subjektif yang dimiliki masing-masing individu merupakan basis untuk melibatkan diri dalam proses eksternalisasi atau proses interaksi sosial dengan individu lain dalam sebuah struktur sosial.

Setiap peristiwa merupakan realitas sosial objektif dan merupakan fakta yang benar-benar terjadi. Realitas sosial objektif ini diterima dan diinterpretasikan sebagai realitas sosial subjektif dalam diri pekerja media dan individu yang menyaksikan peristiwa tersebut. Pekerja media mengonstruksi realitas subjektif yang sesuai dengan seleksi dan preferensi individu menjadi realitas objektif yang ditampilkan melalui media dengan menggunakan simbol-simbol. Tampilan realitas di media inilah yang disebut realitas sosial simbolik dan diterima pemirsa sebagai realitas sosial objektif karena media dianggap merefleksikan realitas sebagaimana adanya.

Berger dan Luckmann berpandangan bahwa kenyataan itu dibangun secara sosial, dalam pengertian individu-individu dalam masyarakat yang telah membangun masyarakat, maka pengalaman individu tidak dapat terpisahkan dengan masyarakat. Manusia sebagai pencipta kenyataan sosial yang objektif melalui 3 (tiga) momen dialektis yang simultan. Pertama, eksternalisasi, merupakan usaha pencurahan atau ekspresi diri manusia ke dalam dunia, baik dalam kegiatan mental maupun fisik. Proses ini merupakan bentuk ekspresi diri untuk menguatkan eksistensi individu dalam masyarakat. Pada tahap ini masyarakat dilihat sebagai produk manusia (society is a human product). Kedua, objektivasi, merupakan hasil yang telah dicapai (baik mental maupun fisik dari kegiatan eksternalisasi manusia) berupa realitas objektif yang mungkin akan menghadapi si penghasil itu sendiri sebagai suatu faktisitas yang berada diluar dan berlainan dari manusia yang menghasilkannya (hadir dalam wujud yang nyata). Pada tahap ini masyarakat dilihat sebagai realitas yang objektif (society is an objective reality) atau proses interaksi sosial dalam dunia intersubjektif yang dilembagakan atau mengalami proses institusionalisasi. Ketiga, internalisasi, merupakan penyerapan kembali dunia objektif ke dalam kesadaran sedemikian rupa, sehingga subjektif individu dipengaruhi oleh struktur dunia sosial. Berbagai macam unsur dari dunia yang telah terobjektifikasi akan ditangkap sebagai gejala realitas diluar kesadarannya, sekaligus sebagai gejala internal bagi kesadaran. Melalui internalisasi manusia menjadi hasil dari masyarakat (man is a social product).

Eksternalisasi, objektivikasi dan internalisasi adalah dialektika yang berjalan simultan, artinya ada proses menarik keluar (eksternalisasi) sehingga seakan-akan hal itu berada di luar (objektif) dan kemudian terdapat proses penarikan kembali ke dalam (internalisasi) sehingga sesuatu yang berada di luar tersebut seakan-akan berada dalam diri atau kenyataan subjektif. Pemahaman akan realitas yang dianggap objektif pun terbentuk, melalui proses eksternalisasi dan objektivasi, individu dibentuk sebagai produk sosial. Sehingga dapat dikatakan, setiap individu memiliki pengetahuan dan identitas sosial sesuai dengan peran institusional yang terbentuk atau yang diperankannya. 
Gagasan Berger dan Luckmann tentang konstruksi sosial berlawanan dengan gagasan Derrida ataupun Habermas dan Gramsci. Kajian-kajian mengenai realitas sosial dapat dilihat dengan cara pandang Derrida dan Habermas, yaitu dekonstruksi sosial atau Berger dan Luckmann, yaitu menekankan pada konstruksi sosial.

\section{Tahap Konstruksi Sosial Terkait Iklan Televisi}

Iklan televisi adalah wacana publik dalam ruang sosiologis yang telah menghidupkan diskusi tanpa henti di kalangan masyarakat. Sekilas wacana iklan televisi ini menunjukkan adanya kekuatan media (khususnya televisi) di dalam mengonstruksi realitas sosial, dimana melalui kekuatan itu, media memindahkan realitas sosial ke dalam pesan media, dengan atau setelah diubah citranya. Kemudian media memindahkannya lagi melalui replikasi citra ke dalam realitas sosial yang baru di masyarakat, seakan realitas itu sedang hidup di masyarakat. Sebagai contoh, iklan televisi susu Dancow, edisi "Aku dan kau suka Dancow". Awalnya ide iklan tersebut diangkat dari dialog seorang ibu dengan anaknya (sebuah realitas sosial lama). Namun begitu dialog itu terjadi dalam media televisi, telah terjadi perubahan citra, bahwa Dancow bukan lagi susu sembarangan. Dancow adalah susu yang luar biasa, apalagi pada akhir dialog, ketika setelah si anak minum segelas Dancow, dia memberitahu ibunya kalau tangannya telah menyentuh telinga. Maknanya dia telah cepat besar hanya dengan meminum segelas Dancow saja, kemudian ada kata-kata yang diperdengarkan, "aku dan kau suka Dancow". Realitas sosial yang menunjukkan anak itu cepat besar karena minum susu Dancow adalah sebuah realitas media yang sengaja dikonstruksi oleh pembuat naskah iklan dan pemesan iklan melalui penciptaan realitas baru, yaitu susu Dancow cara cepat membesarkan anak, karena hanya susu Dancow yang mengandung nutrisi, vitamin, kalori, dan zat-zat lengkap lainnya yang paling sempurna untuk kebutuhan pertumbuhan anak-anak. Iklan Dancow tersebut mengontruksi sebuah realitas sosial bahwa dengan minum susu Dancow, anak akan cepat tumbuh besar. Pada kenyataannya, tidak semua realitas sosial dapat dikonstruksi oleh iklan televisi. Terdapat pula keputusan pemirsa yang justru diskenario oleh faktor lain yang berasal dari luar pengaruh konstruksi iklan dan media massa, seperti teman, orang tua, salesman, kebutuhan yang mendesak, kebiasaan dan fanatisme, tidak ada pilihan dan lain sebagainya.

Untuk mengetahui tahap konstruksi sosial pada iklan televisi, harus terlebih dahulu memahami proses pembuatan suatu iklan, sampai pada tahapan iklan tersebut siap ditayangkan di media. Iklan televisi merupakan iklan yang paling menarik untuk dilihat, jika dibandingkan dengan media cetak, karena iklan seakan-akan menjadi hidup (River, Jenson, \& Peterson, 2003). Yang dimaksud dengan tahap konstruksi iklan atas realitas sosial adalah proses komunikasi antara pembuat iklan dengan khalayak, dimana pada proses ini suatu iklan mengkonstruksi "image" khalayak terhadap suatu produk. Mayoritas biro iklan berasumsi bahwa iklan-iklan dengan kekuatan pencitraan yang kuat akan lebih besar kekuatannya untuk mempengaruhi pemirsa, apalagi kalau pencitraan tersebut dilakukan melalui konstruksi realitas sosial walaupun realitas itu sifatnya semu. Tanpa disadari citra dalam suatu iklan televisi telah menjadi bagian dari kesadaran palsu yang sengaja dikonstruksi oleh copywriter dan visualiser untuk memberi kesan yang kuat terhadap produk yang diiklankan.

Proses konstruksi iklan terjadi melalui beberapa tahapan penting sebagai berikut. Pertama, tahap persiapan materi konstruksi iklan menyiapkan materi konstruksi sangatlah penting dalam skema pembuatan iklan. Diskusi antara pihak pemesan iklan (klien) dengan biro iklan merupakan tahap yang menentukan tema, ide, konsep, pesan apa yang akan menjiwai suatu iklan. Iklan merupakan suatu bentuk layanan publik, yang melaluinya suatu iklan akan terhubung dengan masyarakat luas. Selain itu, iklan juga mengomunikasikan beragam tujuan kepada masyarakat. Tak jarang terjadi bahwa iklan dirasakan kurang rensponsif terhadap nilai-nilai yang tumbuh di masyarakat. Dengan demikian kehadiran para ahli dan tim profesional melalui biro iklan sangat dibutuhkan dalam persiapan materi konstruksi suatu iklan. Kedua, tahap sebaran konstruksi iklan, terkait dengan agenda atau kepentingan tertentu, informasi harus tersebar pada khalayak secara tepat berdasarkan agenda media. Sebaran konstruksi iklan dilakukan melalui strategi media. Konsep iklan pada media elektronik adalah dapat 
dilihat berulang-ulang dengan sebaran waktu yang berbeda-beda sesuai dengan target audience. Ketiga, tahap pembentukan konstruksi realitas berlangsung dengan tujuan untuk meng-konstruksi gagasan tertentu atas dasar agenda dan kepentingan media. Tahap ini terbagi menjadi 2, yaitu: (a) tahap pembentukan konstruksi realitas, merupakan tejadinya pembentukan konstruksi pada masyarakat, penyampaian suatu iklan telah terjadi kepada khalayak. Prosesnya adalah konstruksi realitas pembenaran sebagai suatu bentuk konstruksi iklan yang terbentuk di masyarakat, yang cenderung membenarkan apa saja yang ada pada iklan sebagai suatu realitas kebenaran. Kemudian, kesediaan untuk dikonstruksi, yaitu pilihan orang untuk bersedia jika pikirannya dikonstruksi oleh iklan. (b) Tahap pembentukan konstruksi citra; pada sebuah iklan umumnya disiapkan oleh para pembuat iklan, dalam hal ini adalah biro iklan. Konstruksi citra yang dibangun oleh suatu iklan adalah sebuah konstruksi yang cenderung mengkonstruksi suatu produk sebagai produk yang baik. Dalam lapisan realitas pencitraan, terdapat upaya untuk mempengaruhi khalayak melalui pencitraan. Iklan televisi membentuk realitas melalu pencitraan terhadap produk. Pencitraan dilakukan dengan memberi nilai-nilai tertentu terhadap produk yang diiklankan, antara lain dengan menggunakan ikon-ikon budaya modern dan kelas sosial atas, agar dapat menggambarkan atau menyetarakan produk yang diiklankan dengan ikon kemodernan dan ikon kelas sosial tersebut. Citra adalah bagian penting yang dikonstruksi oleh iklan televisi, namun sejauh mana konstruksi itu berhasil, sangat tergantung pada banyak faktor, terutama adalah faktor konstruksi sosial itu sendiri, yaitu bagaimana seorang copywriter dan visualiser mengkonstruksi kesadaran individu serta membentuk pengetahuan tentang realitas baru dan membawanya ke dalam dunia hiper-realitas, sedangkan khalayak tetap merasakan bahwa realitas itu dialami dalam dunia rasionalnya. Keempat, tahap konfirmasi, merupakan tahapan ketika khalayak memberikan argumentasi dan akuntabilitas terhadap pilihannya untuk terlibat dalam pembetukan konstruksi. Bagi pihak media, tahapan ini diperlukan sebagai bagian untuk memberikan argumentasi terhadap alasan-alasan konstruksi sosial. Sedangkan bagi khalayak, tahapan ini juga sebagai bagian untuk menjelaskan mengapa mereka terlibat dan bersedia hadir dalam proses konstruksi sosial.

Iklan televisi sebagai produk masyarakat yang telah dieksternalisasi oleh khalayak ke dalam dunia sosiokultural. Jika iklan telah ditayangkan, proses selanjutnya adalah upaya untuk menafsirkan iklan tersebut. Hal ini kemudian menimbulkan proses negosiasi makna, yang oleh Berger dan Lukmann disebut dengan Objektivasi. Iklan sebagai media transaksional dan interaksional memiliki kemampuan luar biasa untuk mereproduksi kembali nilai-nilai, citra dan makna yang terdapat pada iklan ke dalam kehidupan sosial. Iklan televisi memiliki kemampuan mereproduksi kembali realitas sosial ke dalam realitas masyarakat. Internalisasi iklan televisi merupakan pemahaman mengenai subjektif dan objektif khalayak dan pembuat iklan televisi. Pemahaman mengenai iklan tersebut merupakan sesuatu yang bermakna, kemudian pemahaman itu diambil dan direproduksi dalam realitas siosial tertentu. Kekuatan media dalam hal ini adalah mengkonstruksi realitas suatu iklan yaitu sebuah realitas yang dikonstruksi berdasarkan sistem yang direkayasa oleh iklan tersebut dengan tujuan meraih keuntungan finansial dari publik untuk mengkonsumsi semua produk yang ditawarkan. Proses konstruksi sosial media terjadi, dimana realitas iklan televisi dibentuk oleh beberapa kelompok yang mengatur konten media, yaitu biro iklan, perusahaan pemesan iklan dan pemirsa iklan televisi itu sendiri. Kelompok-kelompok ini yang menentukan corak dan iklan televisi melalui tahap-tahap konstruksi sosial, dimana dalam tahapan itu realitas sosial iklan televisi dibentuk berdasarkan hubungan-hubungan kekuasaan di antara kelompok tersebut. Sebagaimana yang dimaksud dengan konstruksi sosial, bahwa eksternalisasi, objektivasi dan internalisasi iklan televisi berjalan dalam proses simultan, sehingga makna-makna iklan televisi terbentuk dalam pencitraan iklan televisi. Kemudian terbentuk realitas makna pencitraan dalam dunia iklan televisi, sebagai refleksi dari dunia sosial di sekitarnya. Pada akhirnya, makna-makna itu diangkat dan direproduksi kembali oleh iklan televisi, sebagai realitas sosial baru. 


\section{SIMPULAN}

Basis sosial teori konstruksi realitas sosial adalah masyarakat transisi-modern sekitar tahun 1960-an. Pada saat itu media massa belum menjadi sebuah fenomena yang menarik untuk dibicarakan. Faktor media massa televisi dalam konstruksi sosial ini tidak dimasukkan sebagai variabel atau fenomena yang berpengaruh dalam konstruksi realitas sosial, tidak pernah terpikirkan oleh Berger dan Luckmann dalam gagasan konstruksi sosialnya karena pada saat teori itu dibentuk, konteks sosial tidak melihat bahwa media massa akan berkembang seperti saat ini. Meskipun sejak semula telah disadari bahwa individu juga merupakan kekuatan konstruksi sosial media massa yang tetap saja memiliki kemampuan mengkonstruksi realitas sosial dan keputusan masyarakat. Sehingga teori ini menjadi kurang relevan ketika fenomena media massa menjadi sangat substantive dalam proses eksternalisasi, objektivasi, dan internalisasi.

Realitas iklan televisi membentuk pengetahuan pemirsa tentang citra sebuah produk. Keputusan konsumen memilih atau tidak terhadap suatu produk, semata-semata bukan karena spesifik yang telah terjadi, namun sebenarnya keputusan itu terjadi karena peran konstruksi sosial media massa yang diskenario oleh pencipta iklan televisi. Pada kenyataannya konstruksi sosial atas realitas berlangsung lamban, membutuhkan waktu lama, bersifat spasial, dan berlangsung secara hierarkisvertikal, dimana konstruksi sosial berlangsung dari pimpinan kepada bawahannya, pimpinan kepada massanya, guru kepada muridnya, orang tua kepada anaknya, dan sebagainya.

Ketika masyarakat makin modern, teori dan pendekatan konstruksi sosial atas realitas Peter L. Berger dan Luckmann ini memiliki kelemahan, dengan kata lain tidak mampu menjawab perubahan zaman, karena masyarakat berubah menjadi masyarakat modern dan postmodern. Dengan demikian hubungan sosial antara individu dengan kelompoknya, pimpinan dengan kelompoknya, orang tua dengan anggota keluarganya menjadi sekunder-rasional. Hubungan-hubungan sosial primer dan semisekunder hampir tidak ada lagi dalam kehidupan masyarakat modern dan postmodern. Dengan demikian, teori dan pendekatan konstruksi sosial atas realitas Peter L. Berger dan Luckmann menjadi tidak bermakna lagi. Walaupun sekarang teori ini menjadi kurang relevan karena mengabaikan media massa yang memiliki peran makin substantive, namun sebagai pemikiran yang berakar pada tradisi fenomenologi, Berger dan Luckmann telah menyumbangkan gagasan yang signifikan dalam upaya membangun teori-teori sosiologi pengetahuan (sociology of knowledge) yang juga dapat dirujuk oleh bidang ilmu Desain.

\section{DAFTAR PUSTAKA}

Barker, C. (2005). Cultural Studies: Teori dan Praktik, terj. Tim Kunci Cultural Studies, Jakarta: Bentang Pustaka.

Bungin, B. (2007). Konstruksi Sosial Media Massa. Jakarta: Kencana Prenada Media Group.

Kholifah, S. N., Romadlan, S. (2011). Maskulinitas laki-laki dalam rubrik Man Manual pada majalah perempuan Cosmopolitan Indonesia. Jurnal Ilmu Komunikasi Komunika, 2, 93-98.

Quince. (2014, 20 Mei). Print Design. Stop Violence against Women. Diakses 20 Mei 2014 dari www. quince-creative.com

River, W. L., Jenson, J. W., Peterson, T. (2003). Media Massa dan Masyarakat Modern. Edisi kedua. Jakarta: Kencana Prenada Media Group.

Storey, J. (2007). Cultural Studies dan Kajian Budaya Pop (terj. Laily Rahmawati). Yogyakarta: Jalasutra. 